\title{
Methane Production during Storage of Anaerobically Digested Municipal Organic Waste
}

\author{
Trine Lund Hansen, Svend G. Sommer, Søren Gabriel, and Thomas H. Christensen*
}

\begin{abstract}
Anaerobic digestion of source-separated municipal organic waste is considered feasible in Denmark. The limited hydraulic retention in the biogas reactor (typically $15 \mathrm{~d}$ ) does not allow full degradation of the organic waste. Storage of anaerobically digested municipal organic waste can therefore be a source of methane $\left(\mathrm{CH}_{4}\right)$ emission that may contribute significantly to the potential global warming impact from the waste treatment system. This study provides a model for quantifying the $\mathrm{CH}_{4}$ production from stored co-digested municipal organic waste and estimates the production under typical Danish climatic conditions, thus quantifying the potential global warming impact from storage of the digested municipal organic waste before its use on agricultural land. Laboratory batch tests on $\mathrm{CH}_{4}$ production as well as temperature measurements in eight full-scale storage tanks provided data for developing a model estimating the $\mathrm{CH}_{4}$ production in storage tanks containing digested municipal organic waste. The temperatures measured in separate storage tanks on farms receiving digested slurry were linearly correlated with air temperature. In storage tanks receiving slurry directly from biogas reactors, significantly higher temperatures were measured due to the high temperatures of the effluent from the reactor. Storage tanks on Danish farms are typically emptied in April and have a constant inflow of digested material. During the warmest months the content of digested material is therefore low, which limits the yearly $\mathrm{CH}_{4}$ production from storage.
\end{abstract}

$\mathrm{D}$ URING ANAEROBIC DIGESTION of municipal organic waste in biogas plants, 75 to $85 \%$ of the organic matter is typically degraded (Davidsson et al., 2006), leaving 15 to $25 \%$ that may be degraded in the storage tank where the digested waste is often kept for months before application to agricultural land. According to Danish regulations, organic waste and manure can be spread on land only twice a year to enhance nutrient uptake and limit loss to surface water and ground water. Since $\mathrm{CH}_{4}$ has a global warming potential 23 times that of $\mathrm{CO}_{2}$, $\mathrm{CH}_{4}$ emissions from storage tanks for anaerobically digested organic waste may considerably affect the global warming impact from the waste management system. These emissions have not previously been investigated and the significance of $\mathrm{CH}_{4}$ emissions from digested organic waste is unknown. Therefore, quantification of $\mathrm{CH}_{4}$ emissions from storage tanks is essential for environmental assessment of treatment of municipal organic waste in biogas plants.

The $\mathrm{CH}_{4}$ production from storage of digested waste is governed by degradability of the material, temperature,

T.L. Hansen, S. Gabriel, and T.H. Christensen, Institute of Environment \& Resources, Technical University of Denmark, Building 113, DK-2800 Lyngby, Denmark. S.G. Sommer, Danish Institute of Agricultural Sciences, Foulum, Blichers Allé, Postbox 50, DK-8830 Tjele, Denmark. Received 14 June 2005. *Corresponding author (thc@er.dtu.dk).

Published in J. Environ. Qual. 35:830-836 (2006).

Technical Reports: Waste Management

doi:10.2134/jeq2005.0239

(c) ASA, CSSA, SSSA

677 S. Segoe Rd., Madison, WI 53711 USA and retention time in the storage tank. Whether the produced $\mathrm{CH}_{4}$ is emitted to the atmosphere depends on such factors as the physical features of the storage tank and whether the tank is covered and has gas collection. The Intergovernmental Panel on Climate Change (IPCC) has not developed guidelines for estimating methane emissions from storage of digested organic waste. However, according to the IPCC Good Practice Guidelines (Intergovernmental Panel on Climate Change, 2001), reliable estimates of $\mathrm{CH}_{4}$ emissions from storage of manure should consider the amount of volatile solids (VS), time of storage, $\mathrm{CH}_{4}$ potential of the material (VS basis), and a $\mathrm{CH}_{4}$ conversion factor depending on the manure management system and climate region. Hence, these factors should also be included when determining the potential $\mathrm{CH}_{4}$ emissions from storage of anaerobically digested municipal organic waste.

Methane emissions from storage of anaerobically digested municipal organic waste could not be measured directly, since co-digestion with either manure or sewage sludge is the most common anaerobic treatment technology used for municipal organic waste in Denmark. Accordingly, investigations of emissions from storage tanks have typically concentrated on digested manure and not on municipal organic waste.

The objective of this study was to model possible $\mathrm{CH}_{4}$ production in storage tanks. This modeling was based on measurements of temperature and filling degree in fullscale storage tanks as well as the results of laboratory batch tests, where the methane production of digested municipal organic waste was determined at seven different temperatures $\left(5-55^{\circ} \mathrm{C}\right)$.

\section{MATERIALS AND METHODS}

\section{Methane Production Tests}

The $\mathrm{CH}_{4}$ production of anaerobically digested municipal organic waste was determined by batch tests on the effluent from pilot-scale biogas reactors treating only source-sorted municipal organic waste collected in the city of Aalborg. The stirred pilot-scale reactors of $35 \mathrm{~L}$ were thermophilic $\left(55^{\circ} \mathrm{C}\right)$ and continuously fed with waste diluted to $5 \%$ dry matter. The hydraulic retention time was $15 \mathrm{~d}$, which is a normal hydraulic retention time for Danish biogas plants. The reactors were run for 2 to $3 \mathrm{mo}$ and the effluent for the batch tests was sampled during periods with stable gas production. The pilot-scale biogas experiments are further described in Davidsson et al. (2006). Table 1 shows the chemical composition of the digested waste with respect to dry matter, VS, ash, fat, fibers, nitrogen, phosphorus, potassium, carbon, hydrogen, sulfur, chloride, and calorific value. Furthermore, the enzyme degradable organic

Abbreviations: EDOM, enzyme degradable organic matter; $\mathrm{Nm}^{3}$, normal cubic meter (one cubic meter at $0^{\circ} \mathrm{C}$ and 1 atmosphere); VS, volatile solids (the loss from oxidation of a dried sample at $550^{\circ} \mathrm{C}$, $\%$ of dry matter). 
Table 1. Composition of effluent from anaerobic pilot-scale digestion of source-sorted municipal organic waste (collected and pre-treated in the Danish city of Aalborg) used in the methane production batch tests.

\begin{tabular}{|c|c|c|}
\hline Property & Unit & Value \\
\hline Dry matter & $\%$ of wet wt. & 1.3 \\
\hline Volatile solids & $\%$ of dry matter & 60.3 \\
\hline Ash & $\%$ of dry matter & 39.7 \\
\hline Fat & $\%$ of dry matter & 4.1 \\
\hline Fibers & $\%$ of dry matter & 9.0 \\
\hline N (total) & $\%$ of dry matter & 8.9 \\
\hline $\mathbf{N}\left(\mathbf{N H}_{4}{ }^{+}\right)$ & $\%$ of dry matter & 4.7 \\
\hline $\mathbf{P}$ & $\%$ of dry matter & 1.0 \\
\hline $\mathbf{K}$ & $\%$ of dry matter & 4.9 \\
\hline $\mathbf{C}$ & $\%$ of dry matter & 32.0 \\
\hline H & $\%$ of dry matter & 4.3 \\
\hline $\mathbf{S}$ & $\%$ of dry matter & 0.6 \\
\hline Cl & $\%$ of dry matter & 4.3 \\
\hline Calorific value & MJ/kg dry matter & 14.5 \\
\hline $\mathbf{E D O M}_{\dagger}$ & $\%$ of VS & 56.5 \\
\hline
\end{tabular}

$\dagger$ Enzyme degradable organic matter.

\$Volatile solids.

matter (EDOM) was determined by treating the waste samples with acid and heat followed by washing and treatment with three types of enzyme to determine the enzyme degradable fraction. The analytical procedures are described in detail in Hansen et al. (2006b).

The batch tests for determining the $\mathrm{CH}_{4}$ production of the anaerobically digested waste were performed in triplicate in 2-L glass bottles according to the procedure described in Hansen et al. (2004). The tests covered a broad spectrum of seven different temperatures representing possible conditions in storage tanks in Denmark: $5,10,15,22,28,35$, and $55^{\circ} \mathrm{C}$. No inoculum was used, since the tests should determine the actual $\mathrm{CH}_{4}$ production in a storage tank for anaerobically digested organic waste. For each temperature, parallel tests were performed where cellulose was added to the effluent samples (triplicates) to test whether slow or missing $\mathrm{CH}_{4}$ production was caused by lack of degradable organic matter or microbial inactivity due to low temperature. The batch tests lasted $125 \mathrm{~d}$.

The results from the batch tests were given as the accumulated $\mathrm{CH}_{4}$ production over time $\left(\mathrm{Nm}^{3} \mathrm{CH}_{4} / \mathrm{g} \mathrm{VS}\right.$, where $\mathrm{Nm}^{3}$ is one cubic meter at $0^{\circ} \mathrm{C}$ and 1 atmosphere) per gram of $\mathrm{VS}$ in the digested material.

\section{Temperature and Filling Degree of Storage Tanks}

To estimate the $\mathrm{CH}_{4}$ production from stored anaerobically digested municipal organic waste, the temperature and amount of stored waste must be known. At Danish biogas plants municipal organic waste usually constitutes less than $5 \%$ of the material digested. Manure, sewage sludge, and other organic wastes constitute the main part. Therefore, it was assumed that there were no differences in temperature and filling degree between storage tanks containing only anaerobically digested manure and those containing anaerobically digested manure mixed with municipal organic waste. The temperature and depth of digested manure was measured with 3-wk intervals throughout $1 \mathrm{yr}$ in eight full-scale storage tanks containing anaerobically digested manure.

Three of the eight tanks were separate tanks, tank volumes of 2800 to $4000 \mathrm{~m}^{3}$, located on farms receiving anaerobically digested manure by truck from the biogas plants (Blåskærvej, Lintrup, and Kolstrupvej). The tanks all had a floating surface cover of straw, but no gas collection.

Five of the eight storage tanks were located at biogas plants and directly connected to the main reactor (Linkogas, Filskov, and Århus 1-3). These tanks were all covered and the gas was collected together with gas from the biogas reactor. The volumes of the tanks were 1000 to $3000 \mathrm{~m}^{3}$.

The temperature was measured with thermocouple sensors (Type T, data collection unit Type 1033-130K; Eltek, Haslingfield, UK) mounted on an 8-m pole at $0.1,1.1,2.1,3.1$, and 4.1 $\mathrm{m}$ from the tip inserted in the storage tank. Calibration of the sensors showed variations of $0.5 \%$. The vertical, horizontal, and $45^{\circ}$ temperature profiles were determined; in tanks with low slurry content the horizontal and $45^{\circ}$ angle temperature profiles could not be determined. The depth of the slurry was also measured to determine the volume of digested material in the tanks at each measurement.

\section{RESULTS AND DISCUSSION Methane Production Tests}

Methane production from the digested waste was slow in batch tests at temperatures lower than $28^{\circ} \mathrm{C}$. At $5^{\circ} \mathrm{C}$, the $\mathrm{CH}_{4}$ production was almost undetectable, both for the digested waste and the cellulose sample (Fig. 1), indicating that the microorganisms in the reactors were not capable of degradation at this low temperature. At 10,15 , and $22^{\circ} \mathrm{C}$, the $\mathrm{CH}_{4}$ production was low and the accumulated $\mathrm{CH}_{4}$ production over time was linear (see Fig. 1). At 10 and $15^{\circ} \mathrm{C}$, the $\mathrm{CH}_{4}$ production from the digested waste and the cellulose was of the same order of magnitude, whereas at $22^{\circ} \mathrm{C}$ the cellulose produced 10 times as much $\mathrm{CH}_{4}$ per $\mathrm{kg}$ VS as did the digested waste. This indicates that low degradability of the organic matter in the digested waste limited the degradation process at $22^{\circ} \mathrm{C}$. At 28 and $35^{\circ} \mathrm{C}$, the $\mathrm{CH}_{4}$ production was substantial in the early phases, but decreased after about 70 and $50 \mathrm{~d}$, respectively, indicating depletion of all easily degradable matter in the digested material. Furthermore, within $50 \mathrm{~d}$ at $35^{\circ} \mathrm{C}$, the accumulated $\mathrm{CH}_{4}$ production from the cellulose samples reached the theoretical maximal $\mathrm{CH}_{4}$ potential determined by the Buswell formula (Symons and Buswell, 1933). At $55^{\circ} \mathrm{C}$, the $\mathrm{CH}_{4}$ production rate decreased after $10 \mathrm{~d}$, but continued for another $60 \mathrm{~d}$. The cellulose samples reached the theoretical $\mathrm{CH}_{4}$ potential within $15 \mathrm{~d}$ at this temperature. The microorganisms present in the effluent were already adapted to $55^{\circ} \mathrm{C}$ and therefore fast and effectively degraded easily degradable matter at this temperature. The degradation of slowly degradable organic matter (in this case biogas plant effluent) was, as expected, slower.

The average $\mathrm{CH}_{4}$ production for the effluent material obtained in the batch tests at $55^{\circ} \mathrm{C}$ was $225 \mathrm{Nm}^{3} \mathrm{CH}_{4} / \mathrm{Mg}$ VS (see Fig. 1). In Hansen et al. (2006a) the measured average $\mathrm{CH}_{4}$ potential for municipal organic waste at $55^{\circ} \mathrm{C}$ was found to be $460 \mathrm{Nm}^{3} \mathrm{CH}_{4} / \mathrm{Mg}$ VS with the average EDOM value being about $90 \%$ of VS (equaling $510 \mathrm{Nm}^{3} \mathrm{CH}_{4} / \mathrm{Mg}$ degradable VS). Using the EDOM value in Table 1 as a measure of degradability, the maximal obtainable $\mathrm{CH}_{4}$ production for the digested waste is $285 \mathrm{Nm}^{3} \mathrm{CH}_{4} / \mathrm{Mg}$ VS. Thus, around $80 \%$ of the degradable VS in the digested waste, as determined by the VS and EDOM of the material, was degraded in the batch tests at $55^{\circ} \mathrm{C}$. 

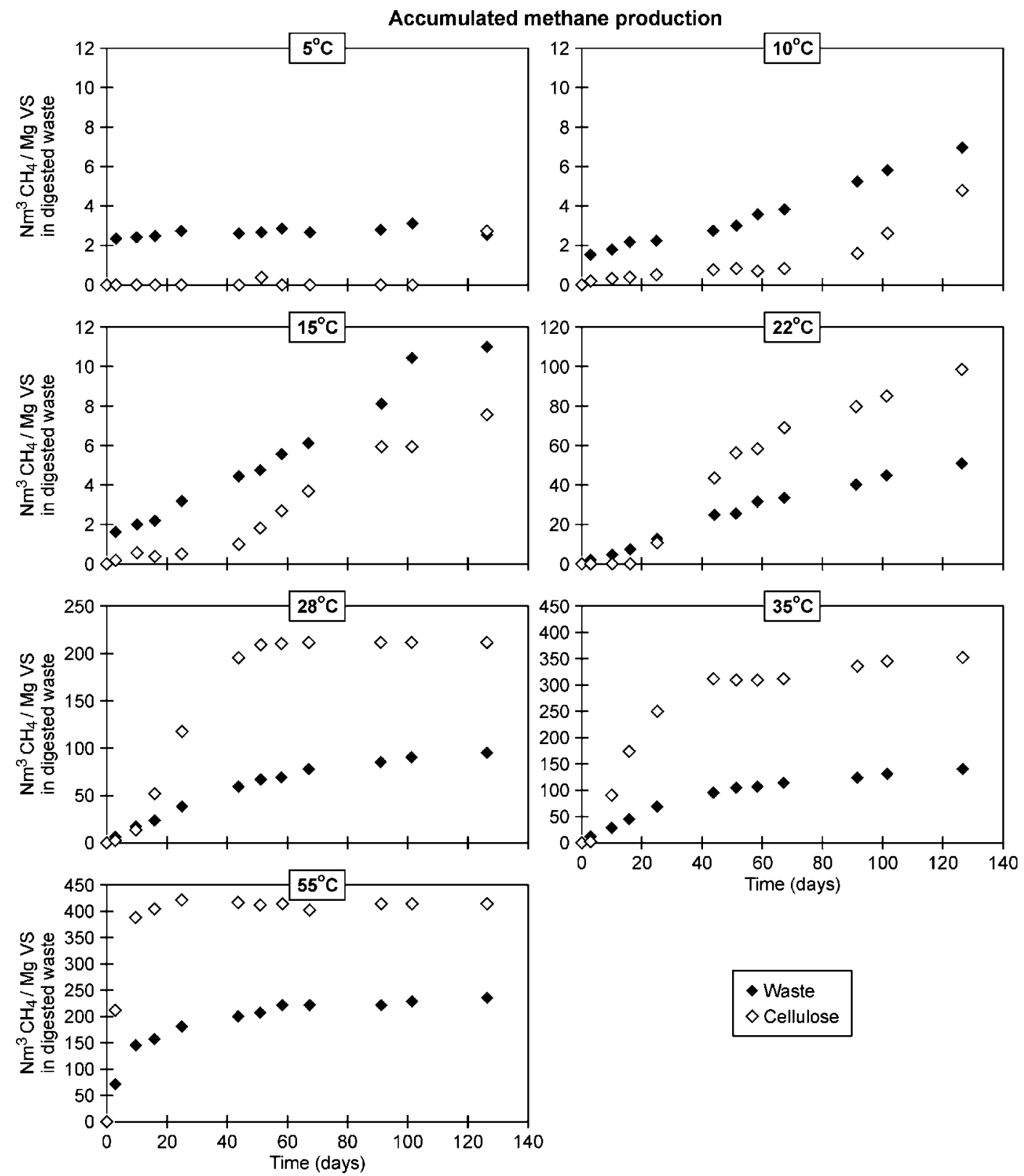

- Waste

$\diamond$ Cellulose

Fig. 1. Accumulated methane production over time (days) for anaerobically digested organic municipal waste and cellulose. The methane production was measured in batch tests (triplicates) at seven temperatures: $5,10,15,22,28,35$, and $55^{\circ} \mathrm{C}^{\circ} \mathrm{Nm}^{3}$, cubic meter at $0^{\circ} \mathrm{C}$ and 1 atmosphere pressure; VS, volatile solids in the organic waste.

\section{The Methane Production Model}

The results from the batch tests showed an approximately linear $\mathrm{CH}_{4}$ production rate over time in the beginning of the tests for the digested waste samples. As the easily degradable organic matter is degraded, the $\mathrm{CH}_{4}$ production decreases until finally no degradable VS is present. The $\mathrm{CH}_{4}$ production rate $\left(\mathrm{Nm}^{3} \mathrm{CH}_{4} / \mathrm{Mg}\right.$ VS h) was determined from the linear part of the $\mathrm{CH}_{4}$ production curves for the investigated temperatures (5$55^{\circ} \mathrm{C}$ ) and is, therefore, valid only within the period where substrate for $\mathrm{CH}_{4}$ production is abundant. For the temperature range 5 to $35^{\circ} \mathrm{C}$ an exponential correlation between temperature and $\mathrm{CH}_{4}$ production rate was found (see Fig. 2 and Eq. [1]). The rate for $55^{\circ} \mathrm{C}$ was not included, since this temperature is normally not relevant for storage tanks under Danish conditions:

$$
E_{\mathrm{CH}_{4}}=0.0004 \mathrm{e}^{0.159 t}, R^{2}=0.98
$$

where $E_{\mathrm{CH}_{4}}$ is the production rate for methane $\left(\mathrm{Nm}^{3}\right.$ $\mathrm{CH}_{4} / \mathrm{Mg} \mathrm{VS} \mathrm{h}$ ) and $t$ is the temperature of the digested waste within the interval 5 to $35^{\circ} \mathrm{C}$.

The results of the batch tests showed a clear linear relation between the log-transformed estimated $\mathrm{CH}_{4}$ production and the inverse temperature in Kelvin $\left(R^{2}=\right.$ 0.98 ) as was also proven for measured $\mathrm{CH}_{4}$ emissions by Husted (1994), Sommer et al. (2000), and Khan et al. (1997). 


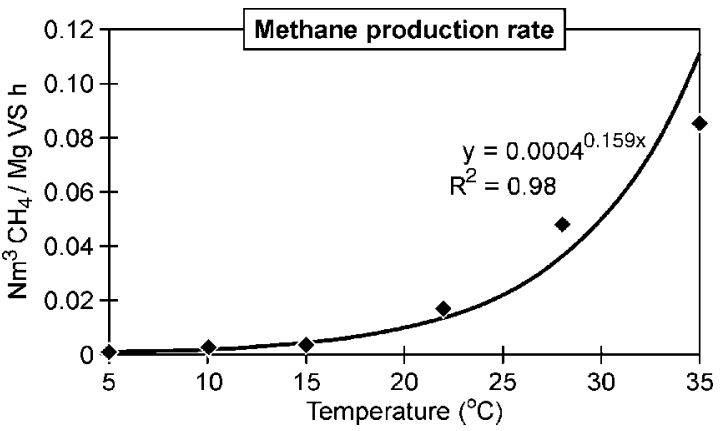

Fig. 2. Estimated correlation between temperature and methane production rate for anaerobically digested organic municipal waste based on laboratory batch tests. $\mathrm{Nm}^{3}$, cubic meter at $0^{\circ} \mathrm{C}$ and 1 atmosphere pressure; VS, volatile solids in the organic waste.

At the lowest temperatures $\left(5\right.$ and $\left.10^{\circ} \mathrm{C}\right)$ the production of $\mathrm{CH}_{4}$ within the first $24 \mathrm{~h}$ was relatively high compared to the overall production. When the effluent entered the batch reactors it still had the temperature of the pilot-scale reactors $\left(55^{\circ} \mathrm{C}\right)$ and, therefore, a comparably higher microbial activity. This activity decreased as the material cooled. However, this initial production was included in the linear determination of the $\mathrm{CH}_{4}$ production rate.

Figure 3 shows the calculated cumulative $\mathrm{CH}_{4}$ production from storage of $1 \mathrm{Mg}$ of VS over $1 \mathrm{yr}$ at different temperatures, assuming constant $\mathrm{CH}_{4}$ production as determined by Eq. [1]. The horizontal line represents the obtainable $\mathrm{CH}_{4}$ potential (VS basis) assuming a maximal $\mathrm{CH}_{4}$ potential of $510 \mathrm{Nm}^{3} \mathrm{CH}_{4} / \mathrm{Mg}$ degradable VS (Hansen et al., 2006a) and a maximal degradability of $56 \%$ of the VS (EDOM value in Table 1). With storage of digested waste over $1 \mathrm{yr}$ at temperatures at $22^{\circ} \mathrm{C}$ or lower, the degradable organic matter is unlikely to be the limiting factor for the $\mathrm{CH}_{4}$ production. At these temperatures, the $\mathrm{CH}_{4}$ production can, therefore, be assumed to be linear over time, which is a basic assumption for the model estimates. At $28^{\circ} \mathrm{C}$ the degradable organic matter will be depleted within approximately $7 \mathrm{mo}$ and at $35^{\circ} \mathrm{C}$ within $4 \mathrm{mo}$. With storage at these temperatures the linear $\mathrm{CH}_{4}$ production cannot be assumed to be valid beyond these time limits.

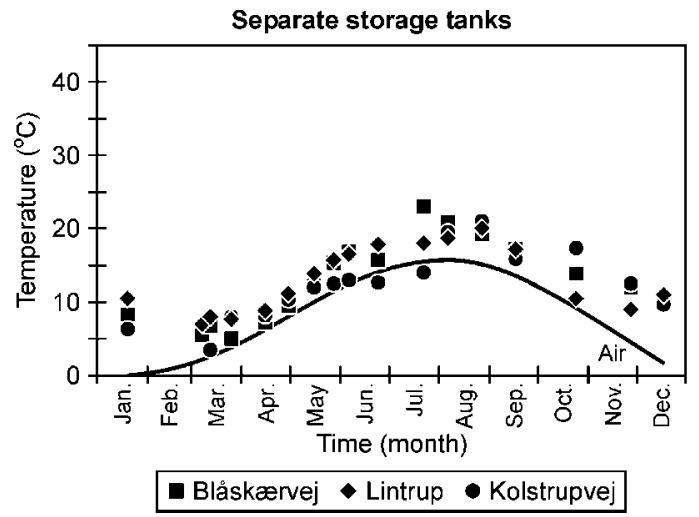

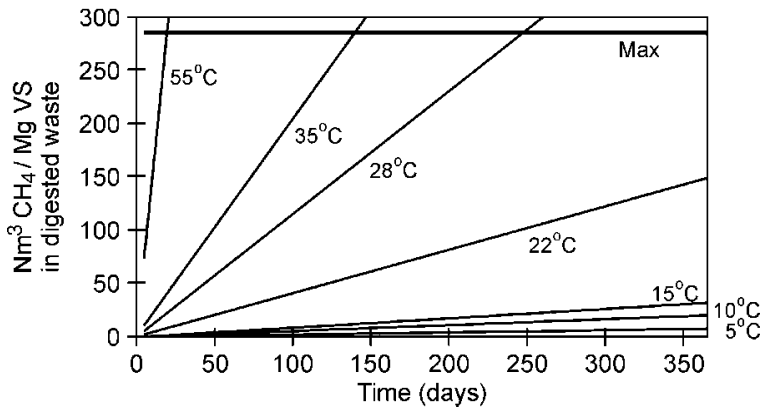

Fig. 3. Linear estimation of methane production from stored anaerobically digested organic municipal waste $(1 \mathrm{Mg}$ VS) over time. The horizontal curve represents the maximal obtainable methane production from the waste. $\mathrm{Nm}^{3}$, cubic meter at $0^{\circ} \mathrm{C}$ and 1 atmosphere pressure; VS, volatile solids in the organic waste.

When using the batch test results for estimation of $\mathrm{CH}_{4}$ production in full-scale storage tanks, it should be considered whether the microorganisms in the full-scale tanks, which are well adapted to the low temperatures, would be more productive than those in the batch tests adapted to $55^{\circ} \mathrm{C}$. It was, however, assumed that the length of the tests $(125 \mathrm{~d})$ allowed adaptation of the microorganisms to the lower temperature and this is, therefore, not considered a crucial uncertainty.

\section{Temperature and Filling Degree}

The horizontal, vertical, and $45^{\circ}$ temperature profiles in the storage tanks showed little variation in space and no clear patterns. Wind and temperature gradients in the stored slurry may enhance natural convection, thereby contributing to homogeneous temperatures in the storage tanks (Olesen and Sommer, 1993). Therefore, the average temperature from each occasion of measuring temperature in the stored slurry was used (Fig. 4) and related to the average monthly Danish air temperature based on $30 \mathrm{yr}$ of monitoring (www.dmi.dk, verified 31 Jan. 2006). Figure 4a shows that the temperature of the separate storage tanks for digested manure was generally slightly higher than the air temperature. This indicates that the temperature in farm tanks may be slightly elevated due to microbial activity in the digested material, but that the temperature is mainly affected by

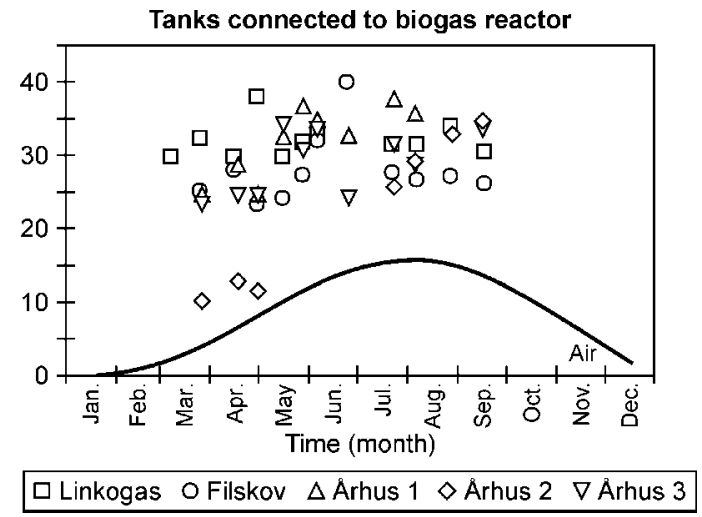

Fig. 4. Temperature in storage tanks measured over $1 \mathrm{yr}$ in Denmark. Figure 4a shows measured temperatures in storage tanks for anaerobically digested manure in separate storage tanks, while Fig. 4b shows measured temperatures in storage tanks for anaerobically digested manure directly connected to the biogas reactor. 


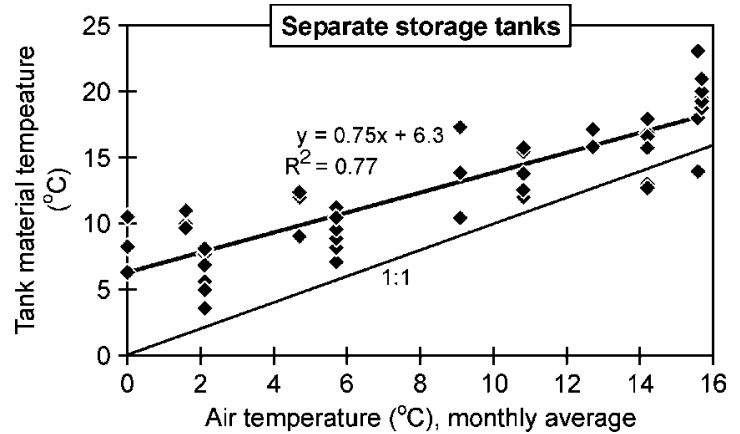

Fig. 5. Correlation between temperature measured in separate storage tanks for anaerobically digested manure and the Danish average monthly temperature.

average air temperature. A linear regression of the temperature of the material in the tanks as a function of the average monthly Danish air temperature (Fig. 5) showed the following correlation:

$$
t_{\mathrm{sl}}=0.75 t_{\mathrm{air}}+6.3, R^{2}=0.8
$$

where $t_{\mathrm{sl}}$ is the slurry temperature in the tank $\left({ }^{\circ} \mathrm{C}\right)$ and $t_{\text {air }}$ is the air temperature $\left({ }^{\circ} \mathrm{C}\right.$, monthly Danish average, www.dmi.dk).

The measured temperatures in storage tanks directly connected to biogas reactors are shown in Fig. 4b. These were significantly higher than the average monthly temperature and mainly depended on the temperature of the effluent from the reactor. The temperature variations in these tanks were larger than in the separate storage tanks due to intermittent inflow of heated effluent from the biogas reactors.

The digested material is applied to agricultural fields in April and the tanks are then emptied. From April the storage tanks are gradually filled until the following spring. This pattern reflects the Danish regulations enforcing farmers to apply slurry in spring at the beginning of the growth season. The addition of slurry to the storage tanks generally varies only slightly, since the biogas plant treats the same amount of manure throughout the year.

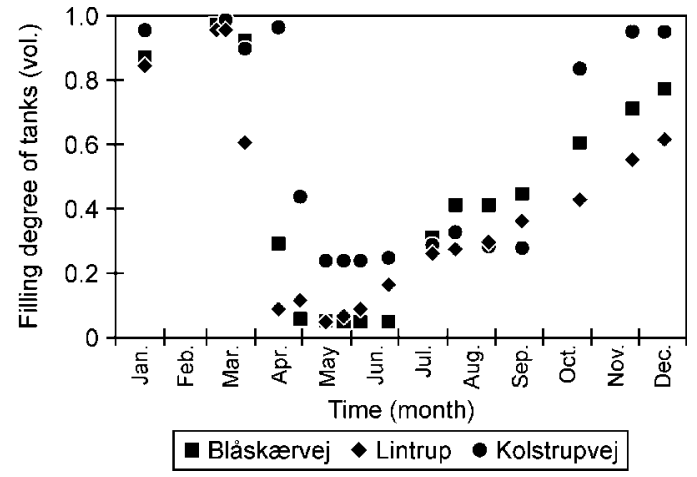

Fig. 6. Filling degree of separate storage tanks for anaerobically digested manure measured over 1 yr.

\section{Estimation of Methane Production in Storage Tanks}

The $\mathrm{CH}_{4}$ production from storage tanks for anaerobically digested organic waste was modeled from Eq. [1] and assumptions based on the field measurements: (i) the temperature of the digested material in the separate storage tanks follows the average air temperature with respect to Eq. [2], (ii) the tanks are emptied in April, and (iii) the tanks have a constant monthly inflow (see Table 2). Over $1 \mathrm{yr}$ the $\mathrm{CH}_{4}$ production from the digested material was estimated to be $0.08 \mathrm{Nm}^{3} \mathrm{CH}_{4} /$ average $\mathrm{Mg}$ digested waste. Assuming $1.3 \%$ dry matter and $60.3 \%$ VS (see Table 1), this $\mathrm{CH}_{4}$ production equals 10 $\mathrm{Nm}^{3} \mathrm{CH}_{4} / \mathrm{Mg} \mathrm{VS}$ in the digested waste or $2 \mathrm{Nm}^{3} \mathrm{CH}_{4} / \mathrm{Mg}$ VS in the waste entering the biogas reactor [assuming $80 \%$ degradation as measured in the pilot-scale reactors in Davidsson et al. (2006)]. This equals $0.4 \%$ of the $\mathrm{CH}_{4}$ potential of the waste going into the biogas reactor (460 $\mathrm{Nm}^{3} \mathrm{CH}_{4} / \mathrm{Mg}$ VS). The estimated $\mathrm{CH}_{4}$ production represents the maximal potential (worst case) emissions, assuming no cover of the storage tank and no oxidation of $\mathrm{CH}_{4}$ in the tank. In Denmark, slurry in open tanks must be covered by a layer of straw, floating granules of leca pebbles, or similar to reduce ammonia emission. It has been shown that these porous covers may sig-

Table 2. Estimated methane production in a 1200- $\mathrm{m}^{3}$ storage tank for anaerobically digested organic waste. The tank is emptied in April, while the inflow of digested material is distributed over the year. $\dagger$

\begin{tabular}{|c|c|c|c|c|c|}
\hline Month & Volume of digested material & VS $\div$ in storage & Temperature, Danish mean & $\mathrm{CH}_{4}$ production rate & Potential $\mathrm{CH}_{4}$ emission \\
\hline & $\mathbf{m}^{3}$ & Mg & ${ }^{\circ} \mathbf{C}$ & $\mathrm{Nm}^{3} \S \mathrm{CH}_{4} / \mathrm{Mg} \mathrm{VS}$ month & $\mathrm{Nm}^{3} \mathrm{CH}_{4}$ \\
\hline January & 850 & 6.2 & 0 & 0.78 & 4.8 \\
\hline February & 950 & 6.9 & 0 & 0.78 & 5.4 \\
\hline March & 1050 & 7.6 & 2.1 & 1.01 & 7.7 \\
\hline April & 1150 & 8.3 & 5.7 & 1.55 & 12.9 \\
\hline May & 50 & 0.4 & 10.8 & 2.84 & 1.0 \\
\hline June & 150 & 1.1 & 14.2 & 4.26 & 4.6 \\
\hline July & 250 & 1.8 & 15.6 & 5.04 & 9.1 \\
\hline August & 350 & 2.5 & 15.7 & 5.10 & 12.9 \\
\hline September & 450 & 3.3 & 12.7 & 3.57 & 11.6 \\
\hline October & 550 & 4.0 & 9.1 & 2.32 & 9.2 \\
\hline November & 650 & 4.7 & 4.7 & 1.37 & 6.5 \\
\hline \multirow[t]{3}{*}{ December } & 750 & 5.4 & 1.6 & 0.95 & 5.2 \\
\hline & & & & & $90.9 \mathrm{~m}^{3}$ \\
\hline & & & & & $0.08 \mathrm{~m}^{3} / \mathrm{Mg}$ \\
\hline
\end{tabular}

$\dagger$ Dry matter content $=1.3 \%$; volatile solid content $=\mathbf{6 0 . 3} \%$ of dry matter.

$\dagger$ Volatile solids.

$\S$ Normal cubic meter (one cubic meter at $0^{\circ} \mathrm{C}$ and 1 atmosphere). 
Table 3. Estimated methane production in a $1200-\mathrm{m}^{3}$ storage tank for anaerobically digested organic waste. The tank is emptied in September, while the inflow of digested material is distributed over the year. $\dagger$

\begin{tabular}{|c|c|c|c|c|c|}
\hline Month & Volume of digested material & VS $\ddagger$ in storage & Temperature, Danish mean & $\mathrm{CH}_{4}$ production rate & Potential $\mathrm{CH}_{4}$ emission \\
\hline & $\mathbf{m}^{3}$ & Mg & ${ }^{\circ} \mathbf{C}$ & $\mathrm{Nm}^{3} \S \mathrm{CH}_{4} / \mathrm{Mg}$ VS month & $\mathrm{Nm}^{3} \mathrm{CH}_{4}$ \\
\hline January & 850 & 3.3 & $\mathbf{0}$ & 0.78 & 2.6 \\
\hline February & 950 & 4.0 & $\mathbf{0}$ & 0.78 & 3.1 \\
\hline March & 1050 & 4.7 & 2.1 & 1.01 & 4.7 \\
\hline April & 1150 & 5.4 & 5.7 & 1.55 & 8.4 \\
\hline May & 50 & 6.2 & 10.8 & 2.84 & 17.5 \\
\hline June & 150 & 6.9 & 14.2 & 4.26 & 29.3 \\
\hline July & 250 & 7.6 & 15.6 & 5.04 & 38.3 \\
\hline August & 350 & 8.3 & 15.7 & 5.10 & 42.4 \\
\hline September & 450 & 0.4 & 12.7 & 3.57 & 1.3 \\
\hline October & 550 & 1.1 & 9.1 & 2.32 & 2.5 \\
\hline November & 650 & 1.8 & 4.7 & 1.37 & 2.5 \\
\hline \multirow[t]{2}{*}{ December } & 750 & 2.5 & 1.6 & 0.95 & 2.4 \\
\hline & & & & & $155.0 \mathrm{~m}^{3}$ \\
\hline
\end{tabular}

$\dagger$ Dry matter content $=1.3 \%$; volatile solid content $=\mathbf{6 0 . 3} \%$ of dry matter. \$Volatile solids.

$\S$ Normal cubic meter (one cubic meter at $0^{\circ} \mathrm{C}$ and 1 atmosphere).

nificantly reduce $\mathrm{CH}_{4}$ emissions (Petersen et al., 2005; Sommer et al., 2000).

Emptying the tanks in spring is an important factor for the magnitude of the $\mathrm{CH}_{4}$ production. Figure 6 shows the lowest filling degree of the storage tanks during the warmest months, where the potential $\mathrm{CH}_{4}$ production rate is the highest. Application of the digested material in the autumn (September) would increase the estimated yearly $\mathrm{CH}_{4}$ production for the average digested material by up to $70 \%$ to $0.13 \mathrm{Nm}^{3} \mathrm{CH}_{4} / \mathrm{Mg}$ of digested waste. These data are shown in Table 3.

The importance of the relatively low Danish monthly average temperature is shown in Table 4 . The $\mathrm{CH}_{4}$ production for a storage tank similar to that in Tables 2 and 3 is estimated assuming the highest monthly average air temperature measured in Denmark since 1874 (www.dmi.dk). The temperature difference is approximately $4^{\circ} \mathrm{C}$ compared to the average temperatures in Table 2 resulting in a $60 \%$ increase in the yearly $\mathrm{CH}_{4}$ production. Assuming elevated temperatures in January, February, and December only (average temperatures for the rest of the year) increased the $\mathrm{CH}_{4}$ production by around $10 \%$ compared to production at average temperature.
The $\mathrm{CH}_{4}$ produced from the digested organic waste could be collected and could contribute to the gas production of the main reactor. This type of gas collection is already in place at many biogas plants, especially for storage tanks directly connected to the biogas reactor. The amount of gas collected in storage tanks may be a significant part of the gas production at the plant. Typically, the retention time in these tanks is 1 to $2 \mathrm{mo}$. Assuming $30^{\circ} \mathrm{C}$ in the storage tank, Eq. [1] estimates a $\mathrm{CH}_{4}$ production of $68 \mathrm{Nm}^{3} \mathrm{CH}_{4} / \mathrm{Mg}$ VS in the digested waste or $13.6 \mathrm{Nm}^{3} \mathrm{CH}_{4} / \mathrm{Mg} \mathrm{VS}$ in the waste entering the biogas reactor. This equals approximately $3 \%$ of the $\mathrm{CH}_{4}$ potential of the waste delivered to the biogas plant (460 $\mathrm{Nm}^{3} \mathrm{CH}_{4} / \mathrm{Mg} \mathrm{VS}$ ).

If the degradation in the biogas reactor is less than the assumed $80 \%$, due to decreased retention time, overload, or operational problems, $\mathrm{CH}_{4}$ production in the storage tanks may be significantly higher than estimated above.

\section{Environmental Assessment}

Environmental assessment of biogas treatment of municipal organic waste, including electricity produced

Table 4. Estimated methane production in a $1200-\mathrm{m}^{3}$ storage tank for anaerobically digested organic waste assuming a monthly average temperature corresponding to the highest measured monthly averages in Denmark since 1874 (www.dmi.dk). The tank is emptied in April, while the inflow of digested material is distributed over the year. $\dagger$

\begin{tabular}{|c|c|c|c|c|c|}
\hline Month & Volume of digested material & $V S \leftarrow$ in storage & Temperature, Danish mean & $\mathrm{CH}_{4}$ production rate & Potential $\mathrm{CH}_{4}$ emission \\
\hline & $\mathbf{m}^{3}$ & Mg & ${ }^{\circ} \mathbf{C}$ & $\mathrm{Nm}^{3} \S \mathrm{CH}_{4} / \mathrm{Mg} \mathrm{VS}$ month & $\mathrm{Nm}^{3} \mathrm{CH}_{4}$ \\
\hline January & 850 & 6.2 & 4.9 & 1.41 & 8.7 \\
\hline February & 950 & 6.9 & 5.5 & 1.51 & 10.4 \\
\hline March & 1050 & 7.6 & 6.1 & 1.62 & 12.3 \\
\hline April & 1150 & 8.3 & 8.4 & 2.14 & 17.8 \\
\hline May & 50 & 0.4 & 13.8 & 4.07 & 1.5 \\
\hline June & 150 & 1.1 & 18.2 & 6.87 & 7.5 \\
\hline July & 250 & 1.8 & 19.5 & 8.02 & 14.5 \\
\hline August & 350 & 2.5 & 20.4 & 8.93 & 22.6 \\
\hline September & 450 & 3.3 & 16.2 & 5.41 & 17.6 \\
\hline October & 550 & 4.0 & 12 & 3.28 & 13.1 \\
\hline November & 650 & 4.7 & 7.7 & 1.96 & 9.2 \\
\hline December & $\mathbf{7 5 0}$ & 5.4 & 5.1 & 1.44 & 7.8 \\
\hline & & & & & $\begin{array}{l}142.9 \mathrm{~m}^{3} \\
0.12 \mathrm{~m}^{3} / \mathrm{Mg}\end{array}$ \\
\hline
\end{tabular}

$\dagger$ Dry matter content $=1.3 \%$; volatile solid content $=60.3 \%$ of dry matter.

\$ Volatile solids.

$\S$ Normal cubic meter (one cubic meter at $0^{\circ} \mathrm{C}$ and 1 atmosphere). 
from the gas and utilization of the effluent on agricultural fields, will often show savings in the impact category "global warming" due to substitution of energy based on fossil fuels and substitution of commercial fertilizers. Kirkeby et al. (2006) evaluated the environmental impacts from different treatment methods of the organic waste from the municipality of Arrhus (Denmark). Based on their data and assumptions, the savings in global warming from biogas treatment of $1 \mathrm{Mg}$ of municipal organic waste could be estimated to be $261 \mathrm{~kg}$ $\mathrm{CO}_{2}$ equivalents. They did not include the $\mathrm{CH}_{4}$ emissions from storage of the digested waste. Estimated according to the proposed model, these emissions would potentially constitute around $8 \mathrm{~kg} \mathrm{CO}$ equivalents/Mg waste (based on the production of $10 \mathrm{Nm}^{3} \mathrm{CH}_{4} / \mathrm{Mg}$ VS in the digested waste, $80 \%$ degradation in the biogas reactor as well as $80 \% \mathrm{VS}$, and $30 \%$ dry matter content in the waste entering the biogas reactor). If emitted to the atmosphere, the potential savings in global warming, resulting from the biogas treatment, will be reduced by $3 \%$.

\section{CONCLUSIONS}

This paper presents a model for estimating the $\mathrm{CH}_{4}$ production from stored digested municipal organic waste. The model takes into account typical patterns of managing the storage tanks and the average temperatures during the months where the digested waste is actually stored.

For a storage tank under typical Danish conditions, the model estimated the $\mathrm{CH}_{4}$ production to be $0.4 \%$ of the $\mathrm{CH}_{4}$ potential of the waste delivered to the biogas plant. Whether the produced $\mathrm{CH}_{4}$ is emitted to the atmosphere depends on the physical features of the storage tank (e.g., cover and gas collection).

For storage tanks directly connected to biogas reactors the temperature was higher and the estimated potential $\mathrm{CH}_{4}$ production corresponded to $3 \%$ of the $\mathrm{CH}_{4}$ potential of the organic waste treated in the biogas plant. The gas produced in these tanks is typically collected and, therefore, contributes to the overall gas production of the biogas plant. Storage in these tanks before transfer to the separate storage tanks may, therefore, decrease the content of degradable VS in the digested waste and thereby limit the methane production and potential emissions from later storage in the separate tanks on the farms.

\section{REFERENCES}

Davidsson, Å., J.C. Jansen, C. Gruvberger, T.L. Hansen, and T.H. Christensen. 2006. Methane yield in source-separated organic fraction of municipal solid waste-thermophilic anaerobic digestion of waste from seven full-scale sorting systems. Waste Manage. (in press).

Hansen, T.L., J.C. Jansen, Å. Davidsson, and T.H. Christensen. 2006a. Effects of pre-treatment technologies on quantity and quality of source-sorted municipal organic waste for biogas recovery. Waste Manage. (in press).

Hansen, T.L., J.E. Schmidt, I. Angelidaki, E. Marca, J.C. Jansen, H. Mosbæk, and T.H. Christensen. 2004. Method for determination of methane potentials of solid organic waste. Waste Manage. 24: 393-400.

Hansen, T.L., H. Spliid, J.C. Jansen, Å. Davidsson, and T.H. Christensen. 2006b. Composition of source-sorted municipal organic waste collected in Danish cities. Waste Manage. (in press).

Husted, S. 1994. Seasonal variation in methane emission from stored slurry and solid manures. J. Environ. Qual. 23:585-592.

Intergovernmental Panel on Climate Change. 2001. Good practice guidance and uncertainty management in national greenhouse gas inventories. IPCC National Greenhouse Gas Inventories Programme, Technical Support Unit, Hayama, Japan.

Khan, R.Z., C. Müller, and S.G. Sommer. 1997. Micrometeorological mass balance technique for measuring $\mathrm{CH}_{4}$ emission from stored cattle slurry. Biol. Fertil. Soils 24:442-444.

Kirkeby, J.T., G.S. Bhander, H. Birgisdottir, T.L. Hansen, M. Hauschild, and T.H. Christensen. 2006. Evaluation of environmental impacts from municipal solid waste management in the Municipality of Århus. Waste Manage. Res. 24:3-15.

Olesen, J.E., and S.G. Sommer. 1993. Modelling effects of wind speed and surface cover on ammonia volatilization from stored pig slurry. Atmos. Environ. 27A:2567-2574.

Petersen, S.O., B. Amon, and A. Gattinger. 2005. Methane oxidation in slurry storage surface crusts. J. Environ. Qual. 34(2):455-461.

Sommer, S.G., S.O. Petersen, and H.T. Søgaard. 2000. Atmospheric pollutants and trace gases-Greenhouse gas emission from stored livestock slurry. J. Environ. Qual. 29:744-751.

Symons, G.E., and A.M. Buswell. 1933. The methane fermentation of carbohydrates. J. Am. Chem. Soc. 55:2028-2036. 